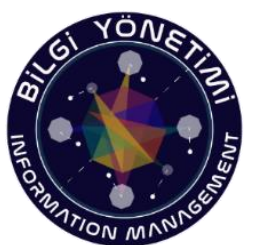

\section{Bilgi Yönetimi Dergisi}

Cilt: 4 Sayı: 2 Yıl: 2021 https://dergipark.org.tr/tr/pub/by

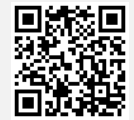

Peer-Reviewed Articles Research Article

\section{Article Info}

Date submitted: Date accepted: Date early view: Date published:

Makale Bilgisi

Gönderildiği tarih: Kabul tarihi:

01.04 .2021 Erken görünüm: 30.06 .2021

Keywords

Museum Education, Museum Studies, New Generation Mueums, Artificial Intelligence

Anahtar sözcükler

Müze Eğitimi, Müze Çalışmaları, Yeni Nesil Müzeler, Yapay Zeka

\section{DOI numarast}

10.33721/by.908020

\section{ORCID}

0000-0002-7513-624X (1)

0000-0002-6119-9928 (2)

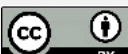

\title{
The Visionary Pros of Artificial Intelligence in Museum Education
}

\author{
Müze Eğitiminde Yapay Zekanın Illeriye Dönük Avantajları
}

\author{
Aslı Asiye ASLAN \\ asliasiyeduman@gmail.com
}

\author{
Ayşe İLHAN \\ Ankara University, Faculty of Educational Science, Professor Dr. \\ ilhan@ankara.edu.tr
}

\begin{abstract}
It is not only the diversity of the objects exhibited but also the methods used to convey the information about these objects that make museums survive. The purpose of these methods is to transfer the museum collection to the future accurately and effectively. While museums host many cultural values, they also aim to make the methods of transferring information about these values qualified and universal. As the perception of the twenty-first century museum visitor profile is shaped by technology, their expectations for the museum experience have also increased. The museum education field, which develops with the modern understanding of museums and provides a lifelong learning experience to the visitors, has an important role in information transfer. Thus, the use of developing technologies in museum education can be beneficial for museum visitors. This study offers a new method proposal that aims to use artificial intelligence, which is considered to be the most important technological development of the twenty-first century in the field of museum education in order to transfer the information about exhibition objects in the most effective way.
\end{abstract}

\begin{abstract}
$\ddot{O} \mathbf{z}$
Müzelerin ayakta kalmasını sağlayan yalnızca sergilenen nesnelerinin çeşitliliği değil bu nesnelere ilişkin bilginin aktarılmasında kullanılan yöntemlerdir. $\mathrm{Bu}$ yöntemlerde amaç, müze eserlerinin geleceğe doğru ve etkili biçimde aktarılmasıdır. Müzeler çok sayıda kültürel değere ev sahipliği yaparken aynı zamanda bu değerler hakkında bilgi aktarım yöntemlerini nitelikli ve evrensel hale getirmeyi hedeflemektedirler. Yirmibirinci yüzyılın müze ziyaretçi profilinin algısının teknolojiyle şekillenmiş olması sebebiyle müze deneyimine dair beklentisi de artmıştır. Çağdaş müzecilik anlayışıyla birlikte gelişen ve ziyaretçilere yaşam boyu öğrenme deneyimi sağlayan müze eğitimi alanı, bilgi aktarımı konusunda önemli bir role sahiptir. Bu yüzden gelişen teknolojilerin müze eğitiminde kullanılması, müze ziyaretçileri için yararlı olabilir. Bu çalışma, yirmibirinci yüzyılın en önemli teknolojik gelişmesi olduğu düşünülen yapay zekânın müze eğitimi alanında kullanılması ve bu doğrultuda sergi nesnelerine ilişkin bilginin en etkili biçimde aktarılmasını hedefleyen yeni bir yöntem önerisi sunmaktadır.
\end{abstract}

\section{Introduction}

A museum, which makes innovative breakthroughs in education, aims to go beyond the passive display of objects. Each object carries information and the museum should provide a structure that preserves the historical consistency of the information and allows the circulation of knowledge without disrupting its authenticity. Therefore, correct and new educational approaches should underlie a newly constructing museum instead of economic and political concerns. A new-wave museum 
should benefit from the technology as much as possible. The structure of traditional museums should be altered in accordance with current developments and the initiative should aim move forward in terms of structural characteristics and improving educational process. In this article, our main aim is making suggestions for implementing artificial intelligence into the museum education and the user interface. For this purpose, we tried to answer three main questions. (1) In different countries of the world (America, Europe and other developed countries), what are the instances of artificial intelligence applications in the museum? (2) Why artificial intelligence applications in the museum education are important and necessary for today and the future? (3) What types of educational activities can be designed using artificial intelligence in museum education? The document scanning method is the main method of this descriptive study. A descriptive research covers the problem as comprehensively as possible and defines carefully (Büyüköztürk, 2016). The scanning method is a research model that aims to define a situation which presented in both past and present as it exists. The research object is tried to be defined in its own conditions. What is important in these studies is to properly observe and document the output (Karasar, 2015). We examined the digital media used in museum education. The literature search is based on hard-copy and digital materials. The information obtained as a result of the research was integrated with our observations and became regular and valid suggestions.

\section{Historical Process of Museology and Museum Education}

The Renaissance movement has steered many fields in the world, as well as in the field of museology. In Europe, the collection owners opened their collections to visit and this is considered as the first initiative of constituting museums as an institution. Each collector has created their own cabinet of curiosity by creating collections in areas of interest. Cabinet of curiosity (cabinet de curiosité or wunderkammer) is defined as making a private collection and exhibiting it with an individual aesthetic (Artun, 2017; Cankaya, 2014). The foundation of the museums started with collecting, which emerged for the first time in the $14^{\text {th }}$ century, and then modern museology formed in the $17^{\text {th }}$ century. It gained the character of an institution with the Renaissance movement. It started to form its identity in the $18^{\text {th }}$ and $19^{\text {th }}$ centuries. The universality is one of the most important features that make a museum successful and educational. In the $21^{\text {st }}$ century, museums that survive through their universality were ironically based on a non-universal basis in the past. By the Renaissance movement, the collectors opened their cabinet of curiosity to visitors, however, they aimed only to organise an exhibition. Their classification method of the objects was done in a subjective manner. However, the timely classification of museum collections is completely far from subjectivity and is universal. Today, museum collections are classified in a rational order and aims to create a universal language. Although the cabinets of curiosity were not classified in this way, the collections were classified according to their forms, measurements, dates, geographies, creators, materials and sometimes écoles and the basis of today's museology have formed. After the Renaissance movement, many European museums opened as modern museums. The collection of modern museums established around the cabinets of curiosity belonging to the dynasty and princes of the period was also composed of the cabinets of curiosity. All these developments not only made the history of art meaningful and formed the basis of museology but also revealed the necessity of museum education. The need for museums to open up to the public and to provide information about collections had made museums a universal and free space by pull away from being inaccessible private and personal spaces. Thus, museums have acquired the feature of not only an architectural building or collection hall, but also an educational space that informs and gives identity.

The basis of museum education is being universal like museology. The universal power of museums also allows their education to be used as an academic field of study. From this point of view, since the Alexandria Museum ( $4^{\text {th }}$ century BC), which is accepted as the ancestor of museums, museums that were intertwined with palaces have also been academic centers. They took under their auspices, as well as the leading artists and authors of their time. In this context, the education and learning function of museums from past to present has been an indispensable field that emerged in the nature of museums. 
Knowledge in modern museums is based on observing and classifying. Correct information provides the correct meaning of the place, work of art, object or theme. Correct information essentially requires an accurate classification and explanation. The understanding of the past and the present and producing a new historical knowledge are only possible if we build our place as what we see on a rational information system. When we look at today's museums, we see that museums have three basic functions: Protection, research and communication. The field that will make all these functions useful is the museum education. The museum education is also an field that can reach different visitor groups by maximizing the educational potential of these three functions (Ertürk \& Uralman, 2012).

Museums have started to open to the public over time and became places where everyone can enter and benefit. The relationship between museums and education gained an importance with the effects of the Industrial Revolution in the $19^{\text {th }}$ century. Just as technological developments affect every field today, the Industrial Revolution had played an effective role in social developments. During this period, many museums aimed to contribute education by creating new education models. During the first half of the $20^{\text {th }}$ century, the museum education has been seen as a system designed to ensure that its participants receive information as permanent as possible. However, starting from the second half of the $20^{\text {th }}$ century, the meaning of education in museums has completely changed. This change has gone beyond the providing information. The given information became rather than a one-sided education, it required a certain participation. Due to these developments and changes, scientific approaches have gained importance in museum education. One of the main reasons that affected the importance of scientific approach was the establishment of international organizations such as UNESCO and International Council of Museums (ICOM). With these developments in the $20^{\text {th }}$ century, museum educators began to develop their educational activities and changed them so different age groups could also benefit. In the 1950s, studies for school groups were the majority, and after 1950, studies for adults started to gain importance. Today, education is accepted as one of the main functions of museums. Museum education programs, which aim to gain experience from the collection and interpret the knowledge learned from it, are now prepared completely visitor-oriented. In many museums, the education department is presented as a separate unit from other departments. This enables to offer, evaluate and develop various educational activities that contribute to both formal and informal education according to the interests and needs of different types of visitors.

\section{1. Post-modern Museum and New Media}

The origin of new artistic and communicative phenomena, which are subject to discussions and productions today, is based on the emergence of different fields of study that have pushed each other to develop one after another in the past. For example, the ability to reproduce the picture and the text has not only expanded the audience but also brought new qualities to artworks. A thought can be copied with revolutionary tools such as the printing press. As a matter of fact, the essence of art has gained new theoretical layers with technical improvements such as reproducibility.

Creating new copies of an artwork by gaining similar identities in different fields has created new discussions within the scope of art and history. Eco (2001) argues that a work of art is always openended and the work is basically never complete. The open work, which can always be intervened in terms of interpretation and repeatability, can accept the acts of destruction and production by the artist and the audience. The original experience resulting from these actions restores the value of the work. Therefore, a work can be beneficial or harmful for the society in a cultural sense and as a jointly designed work, it is attributed to who make and destroy it in the production process. An art piece or a cultural object that was once a common product of society and is now forgotten reminds itself by returning to society when the time comes. Museums, which make this reminder possible in a way, interpret the work in order to develop educational practices in terms of the accuracy and permanence of the information about the work and at the same time take benefits from the freedom to intervene in the work. The intervention here aims an intellectual development and reproduction of knowledge on an individual basis, rather than making changes on a historical work in the physical manner. In this context, the concept of "New Media", which deals with the culture of the digital age and where information can be easily produced, and museum education intersect at important points. 
The New Media, although it cannot be generalized from its name, is a digital field of study that has influenced by theater, cinema, video, photography, painting, graphics, sculpture, architecture, fashion and engineering, moreover, it can use all of these in the transmission of messages. The emergence of the Internet and the rapid spread of digital applications to various fields of art and industry have made the field of the New Media find its place in the literature. By having its own place, the New Media started to have an environment for the examination and discussion in academia. Russian academic Lev Manovich (1999) describes the New Media as a radical cultural revolution. It can be said that the increase of fields where knowledge and materials are produced and becoming easier to access push modern people to be more creative. The gathering of a user-viewer audience of the product that emerges as a result of this creativity naturally determines the cultural and financial value of that product. Considering the New Media as an avant-garde movement enables us to predict future cultural and scientific developments in line with the principle of no boundaries advocated for modern human creativity. So how useful the avant-garde perspective can be for a museum? In order to reveal this, the stance of avant-garde movements against the autonomization and institutionalization of art should be examined first. The New Media aims to offer interactive spaces where individuals, defined as artists and audiences, can engage in common activities, when technology intersects with art in particular. These new interactive spaces enable the artist and the audience to produce jointly, intertwining process and demonstration logic. Therefore, the audience, who is not alienated from the product but freed by being included in the production process, now can define her/himself as active and productive, while the distinction between the artist and the audience disappears and a common 'productive individual' character is born can be said.

The liberating state of an interactive platform is explained by the user-viewer engagement in the production process. According to Jacquas Ranciere's concept of the liberation of the audience, who advocates that just being a passive observer should be disrupted in the $21^{\text {st }}$ century, assigning different roles to the section that causes inaction can improve the social order (Ranciere, 2009). One of the issues that makes the New Media a controversial subject is that individuals can now easily make artistic productions through new tools without considering any artistic discipline or creativity and contribute to the disruption of inaction. The fact that the production conditions provided by corporate, online and offline tools are being supported by mobile and social tools have created this interaction. The functions of technology together with the applications in the fields of history and art continued to reshaping and brought new identities to its users.

The museum education, which is one of the collaborative fields of study history and art, has also reorganized itself during these changes and enabled the participant to participate in the education process - not only as a museum visitor, but as a productive collaborator - without any creativity. So how should the responsibilities of the museum educator be positioned against the tools that make this joint production possible? A requisite for expressing an opinion on an educational process is to interact with that educational setting continuously. This motivates developing new methods depending on the capacity of the environment. As the training tools develop according to the needs, the tendencies of the participants also vary. It is necessary to establish a basic understanding that the learned from the old media can penetrate the new media. This requirement points to a silent media history of the fundamental interaction between the user and the tool, defined by the term "velvet revolution" by Manovich (2007). The idea, which was supported by Bauhaus and other modernist institutions in the 1960s, has been denied by post-modern artists and designers. They also denied that communication can have a universal basis. Post-modernism claims that a cultural work can only be understood in a particular place, time, and audience.

According to this relative positioning, it makes no sense to speak of any natural meaning of an image or object, because all people bring their own cultural prejudices and personal experiences in order to take the act of interpretation. As post-modernism became a dominant ideology in both academia and industry in the 1980s and 1990s, the production process has remained dependent on acts of referring to cultural styles or adapting messages to narrowly defined user communities (Lupton, 1996). Today, mobile and social tools, which are classified within the framework of new media, have become commercial and public interfaces where individuals from outside of the discipline can be active in museum education and define themselves as educators. At the same time, the use of social media 
contributed to both the development and promotion of the work of the museum educators by adding a considerable vision. Thus, the inertia arising from the dependence on technology in education was eliminated when the museum educator became productive. While museum education continues its experimental approach, the academy's continuous discussions in the light of conceptual guidelines requires re-explaining the relationship of the museum education with technology and media. Social media pushes people to be creative, but it is also important that this creativity can serve a purpose and have a visitor. Boris Groys, another media theorist claims that museums intend to restore concrete productivity to their visitors through museum education by better understanding. For this reason, artistic production is based on the interaction between the past and the future in museum education (Groys, 2010).

The museum education supports that the information discovered at the first hand is more permanent by making the value of artistic production visible again while the visitors create original works. Thus, not only the museum educator who prepares the educational program, but also the museum education participant shifts from a passive audience position to an active productive position. For this reason, an audience and service-oriented understanding has settled in museums, and new strategies have emerged as a necessity to ensure the interest and continuity of visitors. Discovering that museums have numerous visitor fractions reflecting "the diversity of society", which is one of the main terms of postmodernism, has been very effective in developing new policies (Yücel, 2012). Culture, which is revealed and shared in the museum experience of the $21^{\text {st }}$ century, not only ensures the permanence of the knowledge, but also gives people a more productive mindset. All these developments and the accelerating change of both perceptions and technology help to quickly identify new needs in education. The museum education is no longer a monotonous field, it has become a field of study that feeds on technology and starts production by instantly contributing to the visitor-place-object relationship. The fact that technological tools create a unique form of interaction between the museum visitor and the objects requires the certain activity conditions that provide this authenticity and the education process that is managed by museum educators.

\section{2. Artificial Intelligence (AI)}

There is no single explanation for AI technology, but in today's general sense, it is described as an field where advanced functions such as learning, perception, establishing relationships between concepts, thinking, problem solving, decision-making and communicating by making inferences from this whole process, which are specific to human intelligence (Nilsson, 2010). It is aimed that these functions correspond to cognitive or autonomous human behaviors. Therefore, this dicipline includes multiple fields of study such as computerized image processing or image recognition, speech or comprehension, text comprehension, language processing, machine learning and robotics. From this point of view, using AI can be explained as a situation beyond simply bringing it to the level of programming and achieving the desired result. However, for the beginning, programming knowledge, mathematics and statistics knowledge and even business knowledge make it easier to benefit from AI technology gradually. AI studies are divided into two as Artificial Narrow Intelligence (ANI) and Artificial General Intelligence (AGI). AGI is, as everyone understands today, the whole of humanoid robot systems in general. The AGI system is biologically inspired by the human nervous system and can continue the process of self-learning and perception like a human. AGI systems are aimed to be able to accomplish certain features such as speaking and reasoning flawlessly. Artificial narrow intelligence is a system developed for the solution of a specific problem. The ANI system learns from data and is different from self-learning systems. Continuity of data entry is required for learning for the functioning of the ANI system.

Today, AI has become one of the most popular fields where countries attach the importance to their investments and allocate large budgets. AI technology, which shapes our present and future, has begun to be used in many fields and has become a part of our daily life. One of the important points to be noted is the purpose of the AI technologies. The purpose is not to produce unguided intelligence, but to produce useful intelligence for the humanity. Therefore, in addition to the researches that try to make AI useful, ethics, law and social perspectives of this subject are also crucial. 


\section{Findings and Evaluation}

$\mathrm{AI}$ is one of the most important technologies of today. It has the potential to provide great benefits in museum education. Looking at the AI studies in the field of education, it can be said that experiments are promising. Using AI in a specific field such as museum education has not been studied in the world, although, it has started to be used as an informative tool in cultural platforms. A video artist and curator Diane Drubay is working in this field in parallel with the implementation of AI. She evaluates the use of $\mathrm{AI}$ in the field of cultural mediation from three different bases: AI as a virtual friend, AI as a historical researcher and AI as a digital replica maker (Museums, 2018).

The main examples of this field are shaped around exactly these three basis. AI can be used as a virtual friend "chatbot" in museums. One of them has been the "chatbot" application in Anne Frank House in Amsterdam. Visitors can ask their historical and cultural curiosities via Facebook Messenger. The Chatbot application is also not only open in Amsterdam but also open to all visitors around the world. Another chatbot-like application is the French AskMona. AI-based application is for cultural conversations and gives recommendations. However, the most popular question asked is "Where are the toilets?". Another example is a mobile application "Art of Art" by IBM Cognitive Bussines-Watson (IBM, 2019). This application provides information about seven artworks in Pinacoteca de Sao Paulo (Figure 1). However, beyond the known headset guidance service, it allows the visitor to chat with the artwork. Visitors can get clear answers by asking their questions and curiosities directly to the work of art. They find answers to all of their questions as they do not selectively ask. Visitors were able to ask questions that they cannot ask a person they do not know, such as the price of the painting, rumors about the artist.

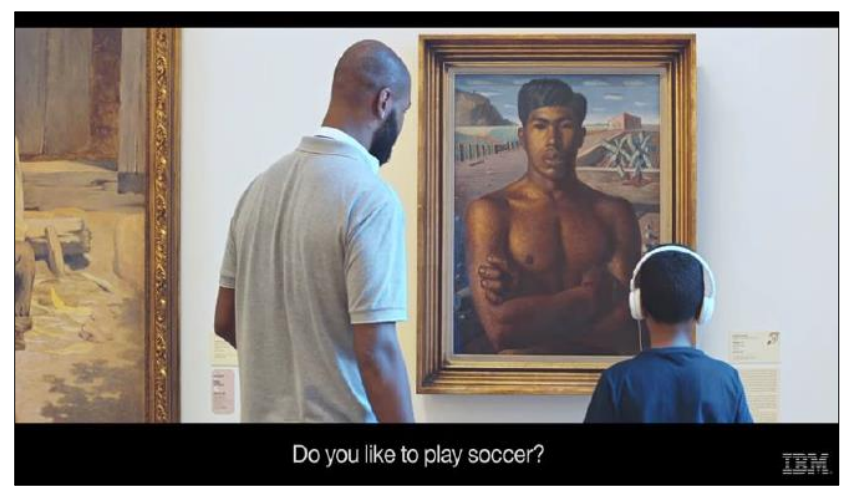

Figure 1. Art of Art,

Source: (IBM, 2019)

The best known application of AI is Google Art and Culture Experiments project as a history researcher (Google, 2011). In the past years, this project has been the most used and recognized AI application in the art history research platform. This project can be used by museums and cultural institutions by using culture and art data. This program, which creates completely unexpected connections between art history periods, movements, styles and techniques by simulating that people cannot easily think of, is an AI-based learning project (Figure 2). At the same time, the project also enables people to take selfies and find their resemblance with works of art, and provides a permanent learning opportunity based on experience by providing information about that art work. 


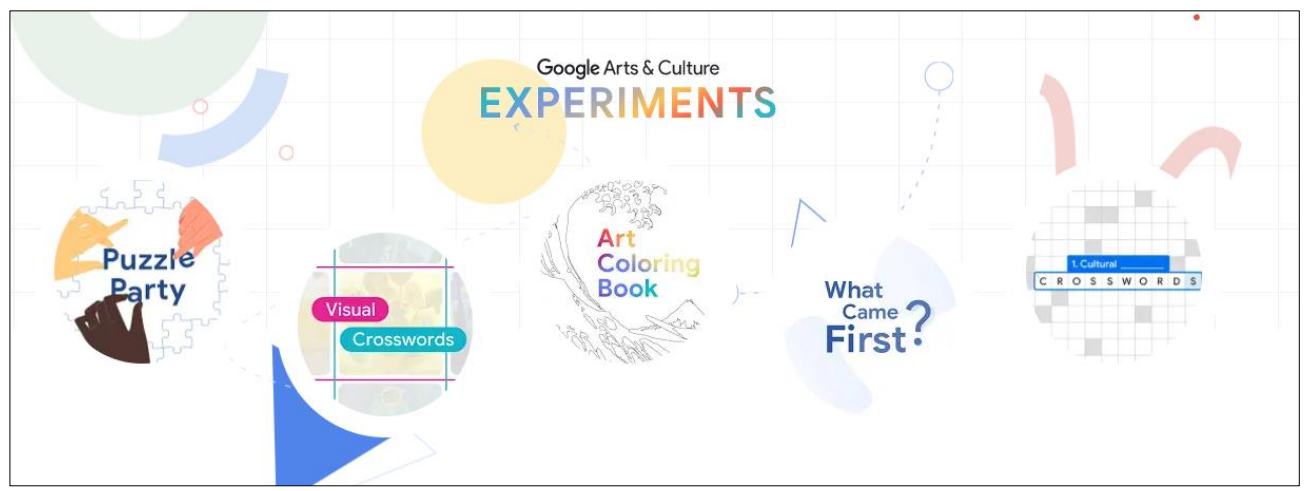

Figure 2. Google Art and Culture Experiments project web site

Source: (Google, 2011)

An example of using AI as a digital copy (replica) producer is the AI-based "recognition" program of the 2016 IK Award-winning Tate UK Museum (Tate, 2016). This program is algorithm software that has established a link between news photography and the art collection of the Tate Art Gallery. The aim of this work is to reconcile the art collection with everyday images. The program creates a visual link between two images, one of which is a work of art and one of the news photograph, by comparing them in terms of similarities.

In 2018, a study was carried out by the Swiss Bern Communication Museum, where visitors can personalize their interaction with a museum by using an AI program (The Museum for Communication, 2018). There are guides that accompanying visitors in the area where the latest technology communication tools are exhibited. Guides are defined as communicators; they make the relationship of the visitors with the museum an individual experience. The participation of the visitors to the games and practices in the exhibition is ensured, and the game or practice they experience is evaluated later, and the guides are directed to visitors according to their wishes and curiosity. While doing this, the guides get help from the AI software and act accordingly. The accurate processing of the data creates a special experience for each visitor.

Another hitting example is the French company Iconem in partnership with Microsoft. Iconem is used to recreate lost and disappearing cultural heritages. The aim was to instill cultural heritage awareness to visitors who can experience these heritage sites in a virtual environment. This work, which creates a memory protected by technology, makes it possible not to forget important historical and cultural heritages such as Palmyra that people have damaged or cannot protect (Figure 3) (UNESCO, 2013). This kind of work allows cultural heritages to be transferred to future generations, at least in a digital environment, in situations such as natural disasters, wars, fires and even vandalism that may occur in the coming years. As construction projects are the elements that destroy cultural heritage, Iconem like projects will be beneficial for handing down the next generation. It will enable the preservation and recall of artefacts and archaeological sites and will ensure that this information is transferred from generation to generation. 


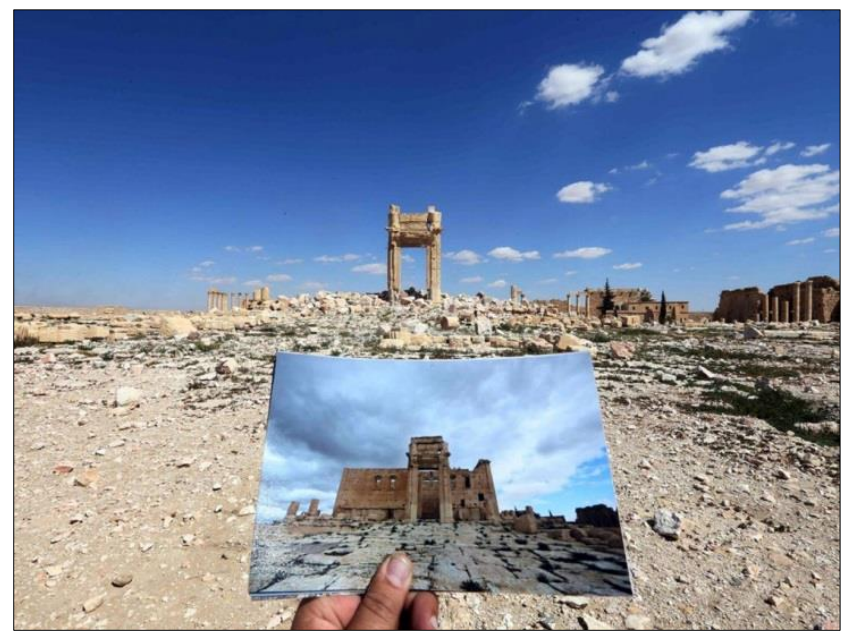

Figure 3. Palmyra, before and after Isis' destruction

Source: (Worley, 2016)

AI s computer software that progresses like a child's learning process. However, the biggest difference from human mind is that it contains a structure that allows all cognitive processes to proceed without error and with infinite data. This structure, which enables computers to think like a human brain, aims to solve complex problems with a human-like method, however, while doing this it can complete a task in a short time and without errors. This situation has also enabled AI studies to be studied under many different categories. AI programs require human knowledge to recognize patterns in complex data, benefit from experience and implement decisions made by humans. This way of working is actually the same as the working principle of the Google search engine, which has now become a part of our lives. For the last 25 years, people have been entering data into computers. These data entries are obtained from 3.5 million searches made on Google every minute. These searches are fuel for selflearning AI applications, in other words each entry helps the AI algorithm to learn. The fact that AI can learn at this speed and carry the acquired information to the next step without any problem such as human errors. This high capacity of it will contribute to new business areas in the near future. AI is used in many fields even today and creates new business fields. Since it will not be possible to take back or stop this continuously developing technology, the most important detail that should not be overlooked in this process is to raise generations that keep up with these developments by raising good, conscientious and qualified people. For example, Facebook AI experts Yann Le Cun and Joaquin Quinonero Candela believe that AI will take on new roles in manufacturing, education, sales, repair and management of smart robots, despite widespread concern over automation. According to the experts, AI and robots will enable the emergence of new sectors that are hard to imagine today (Facebook, 2016). Given these predictions, why shouldn't one of these business fields be museum education?

\section{1. The Information Transfer}

The definition of information has been explained in different ways in many sources. Information refers to the phenomena that individuals acquire learning through research or observation in its most common definition. Information is obtained through learning, research or observation and enables a judgment. Knowledge, which is the result of human thinking activity, is the product of a process. The information process is a process that is built in layers. This process includes observation, research, curiosity and transactional processes (Ayaokur, 2014). In this respect, the process of knowledge is the inclusive of a museum event. The objects and works of art in the museum provide a real knowledge process with the experiences and learning of the visitor. However, the works or artworks in a museum often do not mean anything alone. Therefore, the visitor needs to experience for a better understanding. This experience starts with conveying information about the object or work to the visitor. Regardless of the museum type, objects or artworks in the museum means as much as they seem. 
The museum object can be considered as a document. Viewed from a broad perspective, there is no need that to evaluate the document, semiotics, and the museum object separately from each other. For this reason, the museum object is also a document and therefore it should be accepted as a subject of epistemology (Ayaokur, 2014). This situation possibly will progress in line with the development and change of the information age. AI technology has emerged to meet the knowledge and curiosity needs of people today, just as other similar technologies developed in the past. This system, which includes all situations such as questions, information processing, perception and access information observation, communication and access, information, request to access information services, providing information services, has a working system in parallel with the targeted purposes in museum education and museum education. These goals make it a necessity to use technology in museums and museum education in order to respond to the information needs of the visitor.

The information labeling of the museum objects and art works is the crucial step in the process of perceiving and accessing information. Experience of the knowledge begins with this informational part after seeing the object or art works. Access to information continues with observation, communication and access to the information. All of the information people have is initially observational and observation alone is not enough to inform the visitors. The need for information arises precisely at this point: Accessing the information of the observed object. In this context, a visitor who wants to be informed during a museum visit needs both to reach information based on his/her observations and to be informed. The visitor should request the information. In this respect, the need for information is multidimensional and should aim to contribute to the cognitive access level of the visitor. As museums are viewed from this perspective, they can be true and accurate information providers, as well as educational fields that respond to the information needs of visitors.

Discovering the visitor profiles also plays an important role in developing the services correctly. The age range of the visitor groups, which social group they belong to, their cognitive and emotional characteristics are also the initial characteristics that shape visitors' expectations from the museum. These expectations also determine what should be taken into account when creating museum education. It is very important for a museum educator to anticipate the possibilities of this need, as information needs or curiosities vary according to visitor profiles. So, the main purpose of visiting the museum is to obtain information, regardless of the background of the visitors. In the studies about the information needs of the visitors, the visitors and their needs are defined in three different groups:

1. The visitors requesting information about working hours, fees, museum facilities, what is displayed in the museum, important activities and issues inside the museum.

2. The visitors who request more detailed information about the planning of their visits to the museum, and who pursue educational purposes.

3. Additional links for information sources, museum collections and expert visitors who request more information on specialist fields (Ayaokur, 2014).

All these information requirements and time-changing expectations directly affect museums and educational activities. For this reason, places such as museums that have developed information and research services and can meet and satisfy the information needs of people will ensure their continuity in the future. The museums and their collections established by the collectors are still presented today with the initiatives of wealthy people. The continuity of these places that will make museum education effective is possible thanks to considerable investments. We see that gallery owners like billionaire J. Paul Getty and Charles Saatchi set collections, museums and galleries, and even their standards today. Today, the developing technology has changed even the great art investors. $21^{\text {st }}$ century art investors emerge as the magnates of advertising and computer software. These investors bring new perspectives to the museum and the collection as well as affect the field of museum education.

Bill Gates, the founder of Microsoft, is one of the most important collectors. In addition to the photo collections he bought, he is also the owner of Leonardo Da Vinci's Leicester Codex. Corbis, the subsidiary company of Gates, founded in 1989 , paid more than $\$ 100 \mathrm{~m}$ in copyrights to reproduce the artworks at the Louvre, Hermitage, London National Gallery and the Detroit Institute of Art. Corbis 
company digitized one million images in 1997. Ultimately, the main purpose of all this spent money was to bring art into people's homes. In other words, to improve people's aesthetic perception and to educate them (Freeland, 2008).

The people of the $21^{\text {st }}$ century are in search of not only remarkable museum displays but also places where they can question, learn more, wonder and have fun while doing all these. Museum trainings should go beyond just informing the visitors about the objects and should be based on the visitor's expectations and respond to these expectations. Meeting these expectations in the best way is possible by including developing technology in museum education. Schools can be defined as unclassified and serious environments, unlike museums. The structured education system of schools is somewhat more closed to discussion and questioning than museums. Schools are not the education area where curiosity and creativity are constantly increasing. Museums, on the other hand, are places that bring different perspectives to the individual as they contain an education system that is interesting in terms of being organized spaces and mostly focuses on the individual. The perception of education that focuses on the individual has made the subject of museum education more important. This situation also enabled the museums and their educations that fulfill the requirements of the age to spread faster and to respond to the requests of the visitors faster. Today, the aim of museum education is to reveal the knowledge and skills of the person as well as to allow them to be wondered and questioned freely. This situation accelerates the curiosity and the desire to learn, especially in the new generation museums. In addition to this situation, a museum education developed under the mentorship of the museum instructor can bring efficiency and learning to a higher level and make it permanent. This situation, with the perception of museums as educational environments, has enabled museums to be frequently used in concepts such as education in the museum, the environment where education is held in the museum, and the museum educator. This change has also guided the work done in the field of museum education. Museum education staff and researchers conduct studies that contribute to this field. Visitor satisfaction surveys carried out within the museums and studies conducted in the academic field provide positive contributions and bring new perspectives.

We are responsible for raising individuals who aim to shape technology not who shaped by technology in museum and gallery education. Technology can destabilize the world and people while developing them. So much so that every development that seems normal to us has actually emerged as a new technology, we can see technology everywhere. What we wear, eat and use in our daily life is the result of an ever-evolving technology. Technology changes us without our notice. Museum education is an field that can be highly affected by these developments and can improve itself and its participants. Unlike schools, we can talk about the importance of enabling people to be educated in an autonomous manner and to develop their curiosity in museum education. It is very difficult to understand the needs of the person. The person gets what is needed, they ask fort he information that is required and asks whay they are curious about. In this case, the educator may face endless possibilities. Here, the aim of the museum educator cannot be to educate anyone, because what should be remembered at this point is that nobody educates anyone but it is mentoring. Museum education is also a mentoring job. A pre-prepared mentoring allows for the emergence of new ideas, motivation, creativity, expansion of imagination, learning, curiosity and production. For all these reasons, an AI assistant, which can be used in museum education, can bring the education given to the $21^{\text {st }}$ century conditions into the future and provide different perspectives on museum education. This may allow museums to find unique identities and increase their visitor numbers by highlighting themselves more. Artist and trainer Bager Akbay explained the expectations of new generations as follows (Akbay, 2015).

The museum educator should always develop himself, have a good command of the collection of the museum he is in, and also be prepared for questions that will come during the education. For all these reasons, the museum educator plays a very important role in museums that contain infinite knowledge. The element that will prepare and take the museum educator one step further in the creation of educational programs is the correct processing and use of the knowledge of the museum. In this context, taking advantage of the developing technology in the field of museum education, which is becoming more and more important day by day, will become a necessity rather than a need. When we consider the observation ability of the academy in the context of understanding a historical process, it 
is seen that it does not show the same capability in producing practice compared to producing a theory. However, it is observed that museum and gallery spaces are becoming a more successful environment than academia with each passing day. The reason is that the participants can give feedbacks under the interactive production conditions in museum education and museums can evaluate this.

\section{2. The Museum Education and Artificial Intelligence}

Artificial intelligence studies, which have made serious progress recently, have started to play a role in education. If the museum education succeeds in adapting AI to the technological applications it uses, a revolutionary development will occur in museum education. In order for such an approach not to remain in theory, it is necessary to design a museum education program based on AI. While preparing the education program of a museum, the museum's collection, physical conditions, theme and mission are taken into consideration. The museum education, which is mostly shaped by the feedback of the participants over time, makes the museum an active learning environment. A successful museum education experience helps find ways to relate to and understand artworks. Participants broaden their imaginations and can establish faster and more intelligible connections between the past and the future in their minds. When the museum education is over, what is expected to happen is that the visitor is "learned, content and spiritually strengthened" (Cuno, 2004). When we come to the $21^{\text {st }}$ century, museum education has gone beyond just visiting museums with a guide and has become a field that also receives support from technology.

The museum education packages, which developed with the feedback of the visitors over time, started to need more scientific and definite results. Developing and changing people have changed and developed their expectations and curiosities to the same extent. Museum education is a delicate and complex subject. It requires proper preparation, knowledge and planning. At its core is to love and know artworks but also to reason about the endless possibilities of meaning accumulated around works of art. When we look at all these aspects, an AI program written for the museum education program will give us a large pool of information. A pool with strong results and valid relationships between information can create the right training program. Collecting and processing information, comments and observations bring the museum educator the following: To be able to enrich and develop the experience of the visitors in terms of needs.

Museums are places full of endless possibilities within their collections. These possibilities only come true when instructors skillfully use their vast knowledge and understanding of the objects in their museums and encourage people to think with these objects and embrace the artworks. In simpler terms, exciting the museum visitor to learn about the objects suddenly increases the possibilities. AI can interpret these possibilities faster and more accurately than the human brain. In museum education, what is tried to be taught, or the experience that prompts thinking, is not "how we look or what we seek", but the possibilities of the art experience. As Dewey said almost a hundred years ago, the artwork comes to life in the visitor's experience (Dewey, 2005). Therefore, AI software can be a real and effective aid in this field and generate productive training, but it can never replace an instructor. No matter how advanced the technology develops, the visitor always needs someone to communicate with. Analyzing the link between museum education and technology and obtaining concrete benefits in this regard requires developing an academic approach.

The museum education is a permanent field of experience and learning. This includes all the work done to communicate between the visitor and the museum collection. Museum education programs are designed to enable participants to encounter current meanings about the collection and to connect these meanings with their own experiences. Therefore, in a successful museum education experience, the first goal is to transfer the museum collection to the visitor in an accurate, effective and permanent way. The next goal is not to dictate the fixed and indelible state of certain information to the participant, but to ensure that his/her unique learning ability can be used in different areas and lifelong. A correct and targeted museum education program does not limit the education process to the collection existing in the museum. Therefore, the main purpose of museum education is to create wider connections beyond the existing collection by asking questions and explaining the time, space, language and system of thought through the visuality of objects. 
One of the main reasons why AI is so popular today is that we have a lot of data and we do not have the equipment to process so much data perfectly. AI is a technological advancement that can outperform humans on almost any cognitive task. Researchers offer AI as open platforms to all users, software developers and designers around the world, including ordinary citizens, for expanding the uses of AI. So much so that the replacement of learning systems with AI has begun to provide new perspectives for all employees and researchers in the field of information processing and teaching. Studies on perception and mind have completely changed and developed since Freud, Dewey and even Goodman. In addition to being a cognitive science study that includes fields such as psychology, robot technology, neuroscience, philosophy and AI, it has also contributed to new initiatives on the knowledge of creation, interpretation and understanding of artworks (Freeland, 2008). The use of AI in education has become one of today's research fields. Some of these studies cover a wide spectrum composed of correctly determining the trends of the participants and the accurate and precise analysis of test results. As of 2018, AI operates in ways that work well above human intelligence and give precise results in terms of speed, efficiency and accuracy. The correct development and use of AI creates a scenario that is likely to make the world more productive, conscious and hard-working. The first essential step for this scenario to happen is education. According to the 2018 Davos Annual Report ${ }^{1}$ announced by the world economic form, it is emphasized that $65 \%$ of the children in primary school will work in a job that has not been invented at the moment, and we can only keep up with the pace of this developing technology.

$\mathrm{AI}$ is not only a physical progression that harbors human abilities, but also a perfect thinking system. This intellectual intelligence includes the calculation of probabilities without errors. In a human and knowledge-oriented field such as museum education, this technology can enable the preparation of a near-perfect museum education package. An educator who describes an artwork or an object can easily "get an idea" about the period or features of the work. After putting forward this idea with its reasons, the educator reveals the story of the work with his/her own "experiences" and establishes an interaction with the visitors. The educator made this action with the knowledge and experience he had acquired up to that point. He/She has experienced a similar object itself or a reflection (its printed 2dimensional structure) before, made readings on this object and made detailed investigations. The educator has a very precise knowledge of this work and when he encountered a similar object, his/her biological activity and memory provided sufficient feedback.

\section{Results and Suggestions}

As a result, developing technology makes the world smaller day by day and this situation inevitably reduces the pressures on people, places and even works to grow, change and develop. However, doing useful works in the shrinking world and producing solutions by using the developing technology against the problems we encounter is a concept that the whole world needs. In the face of this need, countries that invest in developing technologies such as AI are increasing day by day. Countries that develop national AI strategies continue to make large investments in this field. Canada became the first in this field, followed by China, Denmark, France, Germany, India, Italy, Japan, Kenya, Malaysia, Mexico, New Zealand, Scandinavian, Poland, Russia, Singapore, South Korea, Sweden, Taiwan, United Arab Emirates, United Kingdom and the United States have announced its national AI strategies.

Technological developments affecting all parts of life also play a major role in museum education. The information transfer process, which is the main task of the museum educator, is largely shaped by technology. It has been observed that AI applications that increase the possibilities of the museum education process are successfully applied in archeology, art and contemporary art museums in various countries. The intended interactive environment went beyond the didactic understanding in education and gave birth to active and productive participants instead of passive visitors.

There is a need for a new generation to take part in the areas where they can make the rules by themselves, shape the game or activity, ask questions and find answers by thinking about it without hesitation. The closest places to create these spaces real are museums. The museum education allows

\footnotetext{
${ }^{1}$ http://www3.weforum.org/docs/WEF_Annual_Report_18-19.pdf
} 
them to experience. However, these trainings should be developed and implemented in the light of developing technology and science. Today, the hypothesis of using an AI "assistant" in museum education may become a necessity in the following years and become a common and useful museum education system.

During a museum education event, each participant has the chance to form their own first impression and opinion. Collective experience arises from individual experiences. An individual experience can permeate others through the satisfaction of curiosity. Satisfaction of curiosity is linked to the responses of the other side. Satisfactory answers will create new questions, and new questions will create new fields of study and experiences. As a suggestion, a museum education program can be set up, in which the AI confronts the participants' collaboration. The purpose of the AI supported museum training package proposal is to support the idea that AI software, which has become a field where the most investment is made among today's technologies, can be used in museum education packages. The winner of the present and the future seems to be the one with the most information, not just the technically flawless algorithm.

We can see the necessity of using AI as an assistant in the museum education event, especially when considered the endless information cycle in museums and the need to bring in this information to visitors/participants by processing the responses correctly. As visitors want to hear correct and often simple answers to their questions and concerns, there should be a responsive facet. This exchange is the most important element that ensures the efficiency and continuity of museum education for all age groups. On the other hand, the museum could correct and enhance its set up too from this mutual experience. The museum educator can perform this information exchange perfectly with the help of a new-age assistant.

\section{Compliance with Ethical Standards}

Conflict of Interest: The authors declare that there is no conflict of interest.

Ethics Committee Permission: Ethics committee permission is not required for this study.

Authors Contribution Rate Statement: The authors declare that they have contributed equally to the article.

\section{Financial Support: No}

\section{References}

Akbay, B. (2015). Maker Eğitim Hareketi [Video File]. Erişim adresi: https://youtu.be/QFisb43qaBE Artun, A. (2017). Mümkün Olmayan Müze: Müzeler Ne Gösteriyor? İstanbul: İletişim Yayınları. Ayaokur, A. (2014). Müzelerde Bilgi Yönetimi. Ankara: Koç Müzesi Vekam Yayınları Araştırma Dizisi.

Büyüköztürk, Ş. (2016). Bilimsel Araştırma Yöntemleri. Ankara: Pegem Press.

Cankaya, İ. (2014). Contemporary Cabinet of Curiosity: An Ethnographic Essay on Collecting, Preserving and Exhibiting. Group Exhibition, CI 2014 Contemporary Istanbul Art Fair, halka art project.

Cuno, J., Montebello, P., Lowry, G.D., MacGregor, N. ve John Walsh Jr. (2004). The Object of Art Museums. In Cuno, J. (Ed.), In Whose Muse? Art Museums and the Public Trust. (Pp. 49-76). Princeton: Princeton University Press.

Dewey, J. (2005). Art As Experience. New York: Perigree Trade.

Eco, U. (2001). Açık Yapıt. İstanbul: Can Yayınları.

Ertürk, N. ve Uralman, H. (2012). Müze Dokümantasyonunun Kapsamı. In Ertürk, N \& H. Uralman (Eds.) Müzebilimin $A B C$ 'si (pp. 57-72). İstanbul: Ege Yayınları.

Facebook Engineering. (2016). AI Education - Introduction to AI [Video File]. Erişim adresi: 
https://fb.watch/4Zep2pUQSO/

Freeland, C. (2008). Sanat Kuramı. Ankara: Dost Yayınevi.

Google. (2011). Arts \& Culture Experiments. Retrieved January 2, 2021, from Google Arts \& Culture. Erişim adresi: https://experiments.withgoogle.com/collection/arts-culture

Groys, B. (2010). Güncel Sanat Nedir? Zamanin Yoldaşlari, 23-39.

IBM. (2019). Artificial Intelligence. Erişim adresi: https://developer.ibm.com/technologies/artificialintelligence/?lnk=hmhpmdev_dw\&lnk2=learn\#_0_1_1_0

Karasar, N. (2015). Bilimsel Araştırma Yöntemi. Ankara: Nobel Akademik Yayıncılık.

Lupton, E. (1996). Learning to Love Software: A Bridge Between Theory and Practice. Artifact 1 (3), 167-177.

Manovich, L. (1999). Avantgarde As Software.

Manovich, L. (2007). After effects, or velvet revolution. Artifact 1 (45-46):67-75. DOI:10.1080/17493460701206744

We Are Museums Staff (2018). Humans versus machines: Who is the better museum mediator? Erişim adresi: https://medium.com/@WeAreMuseums/humans-versus-machines-who-is-the-bettermuseum-mediator-8be6938fe89d.

Nilsson, N. (2010). The Quest for Artificial Intelligence: A History of Ideas and Achievements. Cambridge: Cambridge University Press.

Ranciere, J. (2009). Özgürleşen Seyirci (E.B. Şaman, trans.) Istanbul: Metis Kitap.

Tate Recognition Team. (2016, November 27). Recognition. Erişim adresi: http://recognition.tate.org.uk/\#intro

The Museum of Communication. (2021. April 12). Museum of Communication. Erişim adresi: https://www.mfk.ch/en/home-en/

UNESCO. (2021). Site of Palmyra. Erişim adresi: https://whc.unesco.org/en/list/23/

Worley, W. (2016, April 2). Palmyra: Photographer's powerful before and after photos show city's destruction at the hands of Isis. Independent. Erişim adresi:

https://www.independent.co.uk/news/world/middle-east/palmyra-syria-photos-new-palmyraphotos-show-devastation-artefacts-ruined-isis-a6964766.html

Yücel, D. (2012). Yeni Medya Sanatı ve Yeni Müze. İstanbul: İstanbul Kültür Üniversitesi Yayınları. 